\title{
Pengaruh Variabel Moneter terhadap Variabel Internal Bank Konvensional di Indonesia
}

\author{
Ali Akbar \\ Fakultas Ekonomi, Universtitas Batanghari Jambi, Indonesia \\ Correspondence email: aliakbar060873@gmail.com
}

\begin{abstract}
This research is to know the influence of monetary variables ((interest rate, exchange rate and amount of money supply) on the internal variables of conventional banks (amount of credit and operational expense than operating income (BOPO)). The population in this research is the whole of conventional banks in Indonesia year of 2010-2017. The sampel is the conventional banks by as much as 14 banks, with time series data. The method used is the analysis of partial least square (PLS). The results showed that monetary variables ((interest rate, exchange rate and amount of money supply) have a positive and significant influence on the internal variables of conventional banks (amount of credit and BOPO), where excange rate (rupiah on dollar AS) is the most influential variable on amount of credit and BOPO of conventional banks compared to the interest rate and amount of money supply variable.
\end{abstract}

Keywords: Interest Rate; Exchange Rate; Amount of Money Supply; Amount of Credit; BOPO

\section{PENDAHULUAN}

Menurut Agenor dan Montiel (2008), dalam perekonomian media transmisi pengaruh kebijakan moneter pada dasarnya adalah sektor keuangan, khususnya sektor perbankan, melalui proses penciptaan uang giral, uang kuasi dan kredit. Efektivitas variabel moneter (suku bunga, nilai tukar, jumlah uang beredar) dalam mempengaruhi pendapatan nasional sangat dipengaruhi oleh kinerja sektor perbankan, begitu pula sebaliknya, efektivitas variabel moneter dapat pula menjadi indikator dari kinerja sektor perbankan, disamping efektivitas variabel internal perbankan seperti antara lain kebijakan pemberian kredit dan kebijakan operasional (efisiensi).

Keberhasilan suatu sistem perbankan dapat dilihat dari kinerjanya dalam mengalokasikan sumber dana yang dihimpun untuk mengalirkannya kepada pihak-pihak yang membutuhkan dana tersebut (fungsi bank sebagai intermediary). Nantinya keberhasilan itu diharapkan dapat meningkatkan pertumbuhan ekonomi suatu negara. Hal ini jelas sesuai dengan sasaran yang ingin dicapai dari suatu lembaga keuangan yang didasarkan pada UU No. 10 Tahun 1998 yaitu menciptakan struktur perbankan domestik yang sehat yang mampu memenuhi kebutuhan masyarakat dan mendorong pembangunan ekonomi nasional yang berkesinambungan (Iskandar, 2008).

Sektor perbankan Indonesia, di dalam perkembangannya selalu mengesankan, namun ketika pertengahan tahun 1997, sektor perbankan di Indonesia mengalami krisis skala nasional yang sangat parah (Basalim, 2000). Triyono dan Utomo (2004), selama periode prakrisis, menemukan elastisitas jangka pendek dan jangka panjang instrumen kebijakan moneter (jumlah uang beredar) masing-masing adalah sebesar 0,4012 dan $-1,2938$. Tidak stabilnya sistem konvensional yang ada menyebabkan terjadinya krisis di berbagai belahan dunia secara berulang dari masa ke masa yang membuat masyarakat mengalami kesulitan ekonomi. Peristiwa ini dapat dilihat dari penelitian yang dilakukan oleh Laeven dan Valencia (2008), hasil penelitiannya menemukan bahwa sepanjang tahun 1970-2007 terdapat 447 krisis yang terbagi menjadi 395 krisis keuangan (krisis perbankan, krisis mata uang dan krisis pembayaran hutang pemerintah), 42 twin crisis dan 10 triple crisis. Selain itu, krisis juga pernah melanda Indonesia dan berdampak signifikan terhadap pertumbuhan ekonomi negara ini yaitu seperti yang terjadi pada krisis multidimensi tahun 19971998 dan krisis keuangan global tahun 2007-2008.

Krisis berikutnya adalah krisis yang terjadi pada tahun 2007-2008 yang dikenal dengan subprime mortgage crisis. Berawal dari krisis kredit macet perumahan di Amerika semester akhir 2007, dalam hitungan bulan krisis tersebut menyebar kepada sektor keuangan dan juga sektor riil di berbagai negara kawasan Eropa dan Amerika. Akibat lebih lanjut dari krisis finansial global ini adalah ekonomi dunia yang mengalami perlambatan sangat tajam pada triwulan terakhir 2008. Krisis keuangan yang dialami Indonesia 
pada tahun 2008 berdampak langsung terhadap IHSG yang terus menurun akibat terjadinya capital outflow besar-besaran di pasar saham dan melemahnya nilai tukar mata uang rupiah terhadap dollar AS.

Sementara itu, gejolak instabilitas luar negeri pun terlihat dengan anjloknya nilai tukar rupiah terhadap dollar AS (kurs tengah) yang mencapai angka Rp10.950 per dollar AS pada tahun 2008. Begitupun pada tahun 2013 - 2016 dimana nilai tukar rupiah terhadap dollar AS (kurs tengah) juga anjlok pada angka Rp12.189 - Rp13.795 per dollar AS. Tahun 2013 nilai tukar rupiah terhadap dollar AS yaitu Rp12.189, tahun 2014 nilai tukar rupiah terhadap dollar AS mengalami depresiasi yaitu Rp12.440 dan tahun 2015 nilai tukar rupiah terhadap dollar AS mengalami depresiasi yang cukup tinggi yaitu menjadi Rp13.795, sedangkan pada tahun 2016 nilai tukar rupiah terhadap dollar AS sedikit mengalami penguatan dibandingkan tahun 2015 yaitu Rp13.436 (menguat sebesar Rp.359). Hal ini tidak jauh berbeda dengan dampak yang ditimbulkan oleh krisis multidimensi 1998 di Indonesia yang menyebabkan terjadinya krisis mata uang domestik.

Selama krisis maupun pascakrisis, sektor perbankan mengalami rangkaian deregulasi berkelanjutan (baik dari sisi eksternal maupun internal bank) untuk memperbaiki kinerja perbankan dan mengembalikan kepercayaan masyarakat serta untuk mencegah terulangnya kembali krisis nasional sektor perbankan. Kondisi perbankan saat ini mendorong pihak- pihak yang terlibat di dalamnya untuk melakukan penilaian atas kesehatan bank. Salah satu pihak yang perlu mengetahui kinerja dari sebuah bank adalah investor sebab semakin baik kinerja bank tersebut maka jaminan keamanan atas dana yang diinvestasikan juga semakin besar. Investor dapat mengetahui kinerja suatu bank, dengan menggunakan rasio keuangan. Hal ini sesuai dengan pernyataan Muljono (1999) bahwa perbandingan dalam bentuk rasio menghasilkan angka yang lebih obyektif, karena pengukuran kinerja tersebut lebih dapat dibandingkan dengan bank-bank yang lain ataupun dengan periode sebelumnya.

\section{METODE PENELITIAN}

Salah satu kerangka pemikiran yang dapat digunakan untuk menilai kinerja Bank adalah melalui informasi keuangan yang dikeluarkan oleh Bank, yaitu informasi mengenai kondisi keuangan dan perkembangan hasil usaha suatu Bank. Laporan keuangan merupakan alat utama untuk memberikan informasi kepada para pemakai ekstenal, dimana total kredit dan efisiensi (BOPO) merupakan faktor untuk meningkatkan kinerja keuangan perbankan.

Dari konsep tersebut maka laporan keuangan harus dapat membantu investor dan kreditor untuk menginterprestasikan keadaan suatu Bank. Weston dan Copeland (1997) mendefinisikan laporan keuangan sebagai laporan yang berisi informasi tentang peristiwa perusahaan di masa lampau dan dapat dipakai sebagai dasar untuk penetapan kebijakan perusahaan di masa yang akan datang. Dari laporan keuangan dapat diinformasikan gambaran berbagai aktivitas akuntansi bank secara periodik dan dari laporan keuangan itu pula dapat diadakan penilaian terhadap kinerja keuangan Bank yang bersangkutan. Dalam menilai kinerja keuangan suatu perusahaan, investor dapat menganalisa informasi yang terkandung pada laporan keuangan Bank.

Sektor perbankan sangat penting untuk menunjang dan menggerakkan perekonomian suatu negara dengan memberikan pinjaman (kredit) kepada masyarakat yang membutuhkan untuk mengembangkan usahanya. Oleh karena itu sektor perbankan haruslah sehat dan kuat, sehingga dapat bertahan apabila terjadi krisis ekonomi/keuangan. Hasil penelitian dari Suardani (2009) bahwa variabel moneter (suku bunga, nilai tukar dan jumlah uang beredar) berpengaruh positif terhadap variabel internal bank konvensional, sedangkan Supriyanti (2009) variabel moneter berpengaruh positif terhadap variabel internal bank konvensional tetapi tidak berpengaruh nyata. Bank yang sehat dan kuat dapat dilihat dari performance (kinerja) dari Bank tersebut. Bank yang tidak sehat dan kuat akan mengalami kegagalan dalam menjalankan operasionalnya sehingga hal tersebut dapat berdampak kepada perekonomian suatu negara. Karena pentingnya variabel internal suatu bank (total kredit dan BOPO), maka timbul pemikiran bahwa ada pengaruh variabel moneter (suku bunga, nilai tukar dan jumlah uang beredar) terhadap variabel internal bank konvensional (total kredit dan BOPO) di Indonesia. 


\section{Metode Pendekatan}

Populasi dalam penelitian ini adalah bank umum yang terdaftar di Bank Indonesia periode 2010- 2017. Berdasarkan Stastistik Perbankan Indonesia (SPI) bulan Juni 2017 yang diterbitkan oleh Otoritas Jasa Keuangan dan dapat diakses melalui website www.ojk.go.id pada menu Data dan Statistik-Perbankan, dimana jumlah bank konvensional sebanyak 102 bank.

Sampel merupakan bagian dari populasi yang ingin diteliti. Dari 102 bank konvensional, sampel yang digunakan sebanyak 14 (empat belas) bank konvensional. Adapun kriteria pemilihan sampel adalah sebagai berikut :

1. Bank konvensional yang tercatat di Bank Indonesia dan masih beroperasi selama kurun waktu penelitian (tahun 2010 - 2017).

2. Laporan keuangan Bank yang diteliti (perode tahun 2010 - 2017) tersedia secara lengkap baik di Bank Indonesia (BI), Otoritas Jasa Keuangan (OJK) dan website resmi masing-masing Bank.

Dalam penelitian ini jenis data yang dipergunakan adalah data sekunder yaitu : laporan keuangan triwulanan bank konvensional di Indonesia periode 2010 - 2017 serta data lainnya yang tersedia di Bank Indonesia (BI) dan Otoritas Jasa Keuangan (OJK) dan sumber-sumber resmi lainnya yang mendukung penelitian ini.

Metode metode pengumpulan data di dalam penelitian ini adalah :

1. Metode observasi yaitu dengan pengamatan langsung terhadap Laporan Moneter (suku bunga, nilai tukar, dan jumlah uang beredar) dan Laporan Keuangan Tahunan pada 20 (dua puluh) bank yang menjadi sampel penelitian ini (14 bank konvensional dan 6 bank syariah) periode 2010 - Juni 2017.

2. Metode penelitian kepustakaan (library research) yaitu dengan cara mempelajari dan menelaah berbagai literatur-literatur yang berhubungan dengan masalah yang akan diteliti.

Dalam penelitian ini, peneliti menggunakan metode analisis Deskriptif Inferensial dan Deskriptif Kuantitatif, yaitu :

1. Deskriftif Inferensial yaitu : suatu metode untuk menganalisis data moneter dan keuangan dengan cara analisis statistik induktif.

2. Deskriftif Kuatitatif yaitu : suatu metode yang digunakan untuk menganalisis terhadap data moneter dan keuangan yang ada dengan cara mengaplikasikan teori atau konsep dengan fakta.

Dalam penelitian yang dilakukan data yang diperoleh dan hipotesis yang diajukan akan dianalisis dan diuji dengan alat analisis/uji statistik persamaan struktural berbasis variance atau Structural Equation Modeling (SEM) - Partial Least Square (PLS) dengan menggunakan program/sofware SmartPLS. Adapun pertimbangan menggunakan model SEM-PLS, karena kemampuannya untuk mengukur konstruk melalui indikator-indikatornya, menganalisis variabel indikator, variabel laten, dan kekeliruan pengukurannya serta dapat melakukan analisis secara langsung (tidak satu persatu diregresi) hubungan antara variabel bebas (independen variabel/eksogen) dengan variabel terikat (dependen variabel/endogen).

Menurut Imam Ghozali (2006), Partial Least Square (PLS) merupakan metode analisis yang powerful oleh karena tidak mengasumsikan data harus dengan pengukuran skala tertentu, jumlah sampel kecil. Tujuan Partial Least Square (PLS) adalah membantu peneliti untuk mendapatkan nilai variabel laten untuk tujuan prediksi.

HASIL DAN PEMBAHASAN

Pengaruh Variabel Moneter Terhadap Variabel Internal Bank Konvensional

Tabel 1

Nilai Koefisien dan t-Statistik Analisa Jalur

\begin{tabular}{lcccrr}
\hline Variabel Laten & $\begin{array}{c}\text { Original } \\
\text { Sample }(\mathrm{O})\end{array}$ & $\begin{array}{c}\text { Sample Mean } \\
(\mathrm{M})\end{array}$ & $\begin{array}{c}\text { Standard Deviation } \\
(\mathrm{STDEV})\end{array}$ & $\begin{array}{c}\text { Standard Error } \\
(\mathrm{STERR})\end{array}$ & $\begin{array}{c}\mathrm{t}-\mathrm{Statistics} \\
(\mid \mathrm{O} / \mathrm{STDEV})\end{array}$ \\
\hline VMT -> VIK & 0,955 & 0,956 & 0,004 & 0,004 & 243,955 \\
\hline
\end{tabular}

Sumber : Hasil Analisis

Keterangan :

$\mathrm{VMT}=$ Variabel Moneter

VIK = Variabel Internal Bank Konvensional 


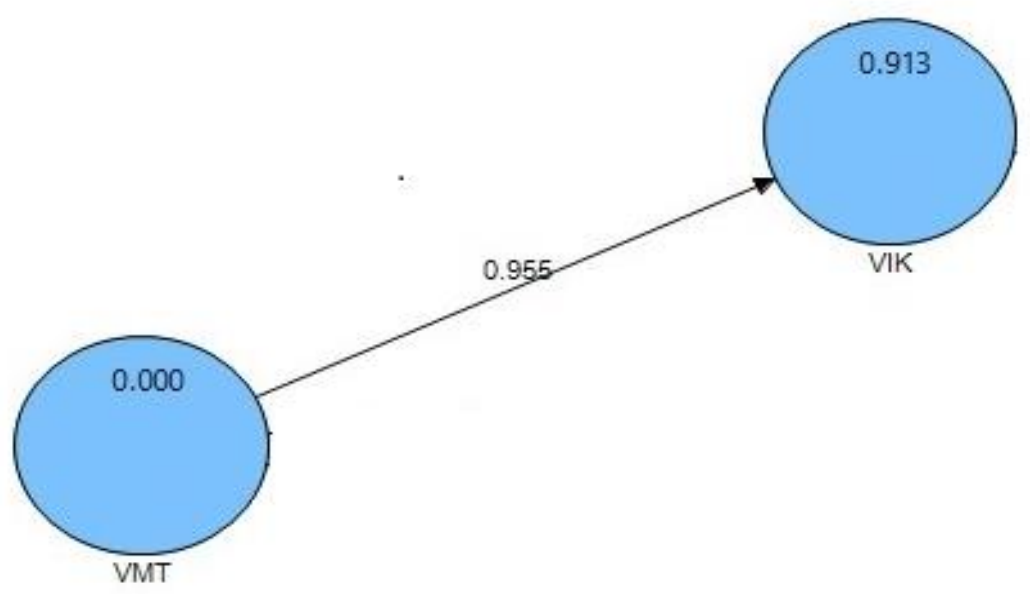

Gambar 2

Pengaruh Variabel Moneter Terhadap Variabel Internal Bank Konvensional

Besarnya nilai variabel moneter (VMT) mempengaruhi besarnya nilai variabel internal Bank Konvensional (VIK), dimana variabel moneter memiliki koefisien jalur 0,955 dan memiliki pengaruh yang signifikan (t.statistik 243,96>1,96 (t-tabel $\propto=5 \%)$ ). Disamping itu nilai original sample estimate yang positif dan tergolong besar menandakan bahwa arah hubungan antara variabel moneter dengan variabel internal Bank Konvensional (VIK) adalah positif, hal ini berarti besar kecilnya nilai variabel internal Bank Konvensional secara nyata ditentukan oleh variabel moneter. Dalam hal ini terima H1 yang berarti variabel moneter berpengaruh terhadap variabel internal Bank Konvensional secara nyata, dengan persamaan model struktural : VIK $=0,955+\varepsilon 1$. besarnya koefisien jalur 0,955 menunjukkan bahwa setiap terjadi perubahan $10 \%$ dalam variabel moneter maka akan meningkatkan variabel internal Bank Konvensional sebesar 9,55\%. Hasil dari pengujian ini sesuai dengan penelitian dari Suardani (2009) bahwa variabel moneter (suku bunga, nilai tukar dan jumlah uang beredar) berpengaruh positif terhadap variabel internal Bank Konvensional, sedangkan Supriyanti (2009) variabel moneter berpengaruh positif terhadap variabel internal Bank Konvensional tetapi tidak berpengaruh nyata. Karim (2006) menyebutkan bahwa meningkatknya suku bunga BI, nilai tukar dan jumlah uang beredar akan diikuti dengan peningkatan suku bunga Tabungan, sehingga akan mengakibatkan nasabah memindahkan dananya ke Bank Konvensional. Hal inilah yang mengakibatkan variabel internal Bank Konvensional berkembang dan akan mempengaruhi kegiatan operasional Bank yaitu dalam hal pembiayaan dan penyaluran dana.

Tabel 2

Nilai Loading Indikator Dengan Konstruk/Variabel Laten

\begin{tabular}{|c|c|c|}
\hline Indikator & VMT & VIK \\
\hline Suku bunga & 0,034 & 0,035 \\
\hline Nilai tukar & 0,987 & 0,963 \\
\hline Jumlah uang beredar & 0,987 & 0,923 \\
\hline Total kredit & 0,984 & 0,925 \\
\hline BOPO & 0,654 & 0,836 \\
\hline
\end{tabular}

Sumber : Hasil Analisis

Keterangan :

$\mathrm{VMT}=$ Variabel Moneter

VIK = Variabel Internal Bank Konvensional 
Koefisien korelasi suku bunga (BI rate) dengan variabel internal Bank Konvensional (VIK) memiliki faktor loading yang kurang valid $(0,035)$ dan memiliki besarnya koefisien jalur yang tidak berbeda nyata. Hal ini berarti variabel suku bunga (BI rate) bukanlah faktor penentu atau bersifat tidak dominan terhadap besar kecilnya variasi besarnya variabel internal Bank Konvensional (VIK). Koefisien korelasi nilai tukar (Rupiah terhadap dollar AS) dengan variabel internal Bank Konvensional (VIK) memiliki faktor loading yang sangat valid $(0,963)$ dan memiliki besarnya koefisien jalur yang berbeda sangat nyata. Hal ini berarti variabel nilai tukar (Rupiah terhadap dollar AS) merupakan faktor sangat penentu atau bersifat sangat dominan terhadap besar kecilnya variasi besarnya variabel internal Bank Konvensional (VIK). Koefisien korelasi jumlah uang beredar dengan variabel internal Bank Konvensional (VIK) memiliki faktor loading yang sangat valid $(0,923)$ dan memiliki besarnya koefisien jalur yang berbeda sangat nyata. Hal ini berarti variabel jumlah uang beredar merupakan faktor sangat penentu atau bersifat sangat dominan terhadap besar kecilnya variasi besarnya variabel internal Bank Konvensional (VIK).

\section{SIMPULAN}

Variabel moneter (suku bunga, nilai tukar dan jumlah uang beredar) berpengaruh positif dan signifikan terhadap variabel internal bank konvensional (total kredit dan BOPO). Nilai tukar (Rupiah terhadap dollar AS) merupakan variabel yang paling berpengaruh terhadap total kredit dan BOPO bank konvensional dibandingkan variabel suku bunga dan jumlah uang beredar.

\section{DAFTAR PUSTAKA}

Angrish, D. 2010. Can Macroeconomic Fundamentals Predict The Performance of Commercial Banks. A Thesis. Faculty of the University of Georgia.

Abdullah, M.Faisal. 2005. Manajemen Perbankan (Teknik Analisis Kinerja Keuangan Bank). UMM Press. Malang.

Agenor, Pierre-Richard and Montiel, Peter J. 2008. Development Macroeconomics. 3rd Edition. Princeton University Press. New Jersey.

Almilia, Luciana Spica, dan Winny Herdiningtyas. 2005. “Analisis Rasio Camel Terhadap Prediksi Kondisi Bermasalah Pada Lembaga Perbankan Periode 2000 - 2002”. Jurnal Akuntansi dan Keuangan Volume 7 Nomor 2, STIE Perbanas, Surabaya.

Basalim, Umar, Moch.Rum Alim, dan Helma Oesman. 2000. Perekonomian Indonesia : Krisis dan Strategi Alternatif. Jakarta. Universitas Nasional Jakarta dan PT Pustaka Cidesindo.

Gelos. 2006. Bank Relationship and Firm Performance: Evidence from Thailand before The Asian Financial Crisis. Journal of Bussiness Finance and Accounting.

Ghozali, Imam. 2006. Structural Equation Modeling: Metode Alternatif dengan Partial Least Square. Universitas Diponegoro. Semarang.

Iskandar, Syamsu. 2008. Bank dan Lembaga Keuangan Lain. PT.Semesta Asa Bersama. Jakarta.

Karim, Adiwarman A. 2006. Bank Islam: Analisis Fiqih dan Keuangan. PT.Raja Grafindo Persada. Jakarta.

Kesumayuda, I B Nyoman, Made Suyana Utama, dan I B P Purbadharmaja. 2016. Analisis Faktor Internal dan Eksternal Yang Mempengaruhi Kinerja Keuangan Bank Pembangunan Daerah di Indonesia Periode 2010 - 2013. Jurnal Buletin Studi Ekonomi. Vo.21. No.1. Universitas Udayana.

Laeven, Luc and Valencia, Fabian. 2008. Sistemic Banking Crises : A New Database. IMF Working Paper.

Lestari, Maharani Ika dan Toto Sugiharto. 2007. Analisis Kinerja Bank Devisa dan Bank Non Devisa dan Faktor-Faktor Yang Mempengaruhinya. Jurnal Proceeding PESAT (Psikologi, Ekonomi, Sastra, Arsitek \& Sipil). Vol.2. Fakultas Ekonomi. Universitas Gunadarma.

Maisel, Sherman J. 1981. Risk and Capital Adequacy In Commercial Banks. NBER Monograph. The University of Chicago Press.

Mangkoesoebroto, Guritno. 1993. Ekonomi Publik. Edisi 3. BPFE. Yogyakarta.

Martono dan D.Agus Harjito. 2002. Manajemen Keuangan. Edisi Pertama. Cetakan Kedua. Ekonisia. Yogyakarta.

Muljono, Teguh Pudjo. 1999. Analisa Laporan Keuangan Untuk Perbankan. Edisi Revisi 1999. Cetakan 6. Djambatan. Jakarta. 
Octaviyanty, Kamalia, Sunu Priyawan, dan Tri Ratnawati. 2013. Analisis Faktor Internal dan Eksternal Yang Mempengaruhi Kinerja Bank Umum di Indonesia Periode 2008-2011. DIE. Jurnal Ilmu Ekonomi \& Manajemen. Vol.9. No.1.

Olajide, Olubayo Thomas., Asaolu, Taiwo., dan Jegede, Charles Ayodele. 2011. The Impact of Financial Sector Reforms on Banks Performance in Nigeria. The International Journal of Business and Finance Research. Vol. 5. No. 1.

Ponco, Budi. 2008. Analisis Pengaruh CAR, NPL, BOPO, NIM Dan LDR Terhadap ROA Pada Perusahaan Perbankan Yang Terdaftar di Bursa Efek Indonesia Periode 2004-2007. Tesis. Program Studi Magister Manajemen. Program Pascasarjana. Universitas Diponegoro. Semarang.

Putranti, Ratih Dwi. 2015. Analisis Pengaruh BOPO, NIM, Suku Bunga, Dan Nilai Tukar Valuta Asing Terhadap Profitabilitas Bank Umum. Jurnal Akuntansi. Universitas Dian Nuswantoro. Semarang.

Suardani, A.A.Putri. 2009. Pengaruh Beberapa Variabel Ekonomi Makro Terhadap Kinerja Keuangan dan Return Saham Perusahaan Pada Industri Manufaktur di Pasar Modal Indonesia. (Online). Jurnal Bisnis dan Manajemen.

Sukarno, Kartika Wahyu dan Syaichu, Muhamad. 2006. Analisis Faktor-Faktor Yang Mempengaruhi Kinerja Bank Umum di Indonesia. Jurnal Studi Manajemen \& Organisasi. Volume 3. Nomor 2. Universitas Diponegoro. Semarang.

Supriyanti, Neni. 2009. Analisis Pengaruh Inflasi dan Suku Bunga BI Terhadap Kinerja Keuangan PT.Bank Mandiri, Tbk Berdasarkan Rasio Keuangan, (Online). Jurnal Bisnis dan Manajemen.

Surifah. 2002. Kinerja Keuangan Perbankan Swasta Nasional Indonesia Sebelum dan Setelah Krisis Ekonomi. Jurnal Akuntansi \& Auditing Indonesia. Vol.6. No.2.

Triyono dan Yuni Prihadi Utomo. 2004. Studi Komparasi Efektivitas Pengaruh Kebijakan Fiskal dan Moneter dalam Perekonomian Indonesia. Ekobis. Vol.5. No.1a, April : p.79-91.

UU No.10 Tahun 1998 Tentang Perubahan Atas UU Nomor 7 Tahun 1992 Tentang Perbankan.

Weston, J, Fred and Copeland, E, Thomas. 1997. Manajemen Keuangan. Edisi Kesembilan. Binapura Aksara. Jakarta.

World Bank. 1997. World Development Report 1997. New York : Oxford University Press, Inc. 